\title{
The Impact of E-Learning on some Psychological Dimensions and Academic Achievement
}

\author{
Seyedeh Monavar Yazdi ${ }^{1}$ and Ghazal Zandkarimi ${ }^{2}$ \\ Alzahra University \\ Faculty of Educational Science and Psychology
}

\begin{abstract}
This study was conducted to investigate the effect of e-learning with teacher Tele working and virtual presence of parents on test anxiety, achievement motivation and academic achievement among high school students. The samples of 200 students were selected randomly among high school students in Tehran. With regard to educational courses, equally 100 participants were assigned in the experimental and the control group. The research instruments were Leitnerpro.com ${ }^{3}$ site, achievement motivation questionnaire and test anxiety scale. The study method for students was Leitnerpro.com with emphasis to information processing approach. Their learning progress was assessed by their teachers and parents through Tele working every day, for 4 months. GPA from 2 terms used for academic achievements. The students' achievement motivation and test anxiety were measured at beginning and the end of their educational term which were assigned for pre-test and posttest scores. The results of covariance test on data showed significant at 0.01 significant levels for all of the variables. The results represented that e-learning in present site with teachers Tele working and parent's virtual presence were more effective than control group. It showed reduction on the test anxiety and increased the achievement motivation and academic achievement scores among high school students.
\end{abstract}

Keywords: Academic Achievement, Achievement Motivation, E-Learning, Tele Working, Test Anxiety

\section{Introduction}

E-learning is the use of telecommunication technology to deliver information for education and training. As information and communication technology progresses, e-learning is emerging as the paradigm of modern education. The great advantages of e-learning include making interactions between learners and instructors, or learners and learners through the asynchronous and synchronous learning network models. E-learning characteristics fulfill the requirements for learning in modern society and have created great demand for e-learning from businesses and institutes of higher education (Katz, 2002). Electronic learning has now been recognized to have eased out learning process and have developed achievements of students with the ease of technology usage. Electronic learning or the online education has

\footnotetext{
${ }^{1}$ Seyedeh Monavar Yazdi, Professor, Alzahra University, Tehran. Email: smyazdi@alzahra.ac.ir

${ }^{2}$ Ghazal Zandkarimi, PHD, General Psychology, Alzahra University, Tehran. Email: ghazalzandi@ student.alzahra.ac.ir

${ }^{3}$ A site is developed by Partovi and Zand Karimi (2010), Registration Number: 209397.
} 
transformed traditional classroom strategies by broadening its scope which is no more than a genius way of reaching out to those who do not have the necessary resources to finish schooling (Paechter and colleges, 2010). Iran is a country that is making progress in the field of virtual education and has many disadvantaged areas without any school for children. On the other hand, UNESCO has a lot of interests in such areas, where children are deprived from general education. The e-learning for students in these areas are very important in educational science. This technology can improve students' academic achievement as well as having reached to a certain standard level of education with no access to schools, then by this technology they will achieve to educational provisions. UNESCO has a lot of interests in elearning and designation of more useful equipped systems for these areas (Magnoson, Dall \& Chiland, 2010). Investigation about the learning problems and finding the ways to promote students' learning study materials at schools as well as for university students was a part of the present research plan.

Effective e-learning comes from using information and communication technologies (ICT) to develop educational opportunity and help students to develop their skills. While longitudinal studies are done, most of evidences suggests that e-learning can deliver substantial positive effect such as: students' engagement, teachers' positive attitudes and personalized learning, family interaction and parental involvement (Intel, 2009). Richard (2004) examined the differences between the academic achievements of postgraduate business students. His results showed students, on the average, did better in the e-learning mode. Age and gender did not appear to moderate performance in any way except for those students under 33 who did better, on the average, in the e-learning mode. Terrell (2003) also noted that the presence of virtual learning styles can influence the prediction of student's success in web based learning environments. His follow up study on 159 doctoral students majoring computing technology in education showed that students were generally able to adapt their learning style in order to succeed in a web based environment. However, students with a preference for systematic planning and abstract conceptualisation of a situation were likely to be more successful than students preferring concrete experience and interaction with other students. On the aspects of cognitive process on e-learning, Yazdi and Zandkarimi (2012) have found that correlation between cognitive outcomes and using technology between students is significant. They indicated that using technology instruments can clearly increase students' cognitive outcomes. Andrewartha and Wilmot (2001) also have studied the use of multimedia to argue the studants' learning as a strategy for enhancing active learning among students. In this study they developed a multimedia course on 'editing' to replace traditional classroom based teaching on editing subject. The researchers concluded that multimedia was as good as traditional classroom instruction and sometimes is better, because students were more actively engaged with the material.

According to our investigation, there were no study about the effect of e-learning with teacher Tele working and virtual presence of parents among high school students with regard to their test anxiety, achievement motivation and academic achievement. In many cases, low achievement motivation can be seen in high school students (Kenny \& collages, 2010). Test anxiety is a problem in many cases among students (Larson \& rose, 2011). The purpose of this study was to examine the effect of e-learning with teachers Tele working and virtual 
presence of parents on test anxiety, achievement motivation and academic achievement among high school students. The questions were posted in this study were whether e-learning could reduce test anxiety? Or could it increase achievement motivation and academic achievement?

The proposed hypotheses were:

1. E-learning is effective on the test anxiety of high school students.

2. E-learning is effective on the achievement motivation of high school students.

3. E-learning is effective on the academic achievement of high school students.

\section{Method}

The method used in this research was an experimental approach with a control group. The Leitnerpro.com site was the research environment. The statistic population were high school students in Tehran. A sample of 200 high school students were selected randomly, and with regard to educational field of study, equally assigned to the experimental and the control group. Both groups took test anxiety scale (TAS) (Sarason, 1980) and achievement motivation questionnaire (Hermans, 1970), at the beginning and end of their educational term. In order to assess students' academic achievement, their first term GPA were as a pre-test and the second term GPA were as a post-test (in a year of study). Participants in the experimental group studied all of their courses in Leitnerpro.com site for 4 months (duration of the term study). Independent variable was the method of study, i.e., e-learning in Leitnerpro.com site, and dependent variables were test anxiety, achievement motivation, and academic achievement. The conceptual model of the e-learning site features in this research is shown at below:

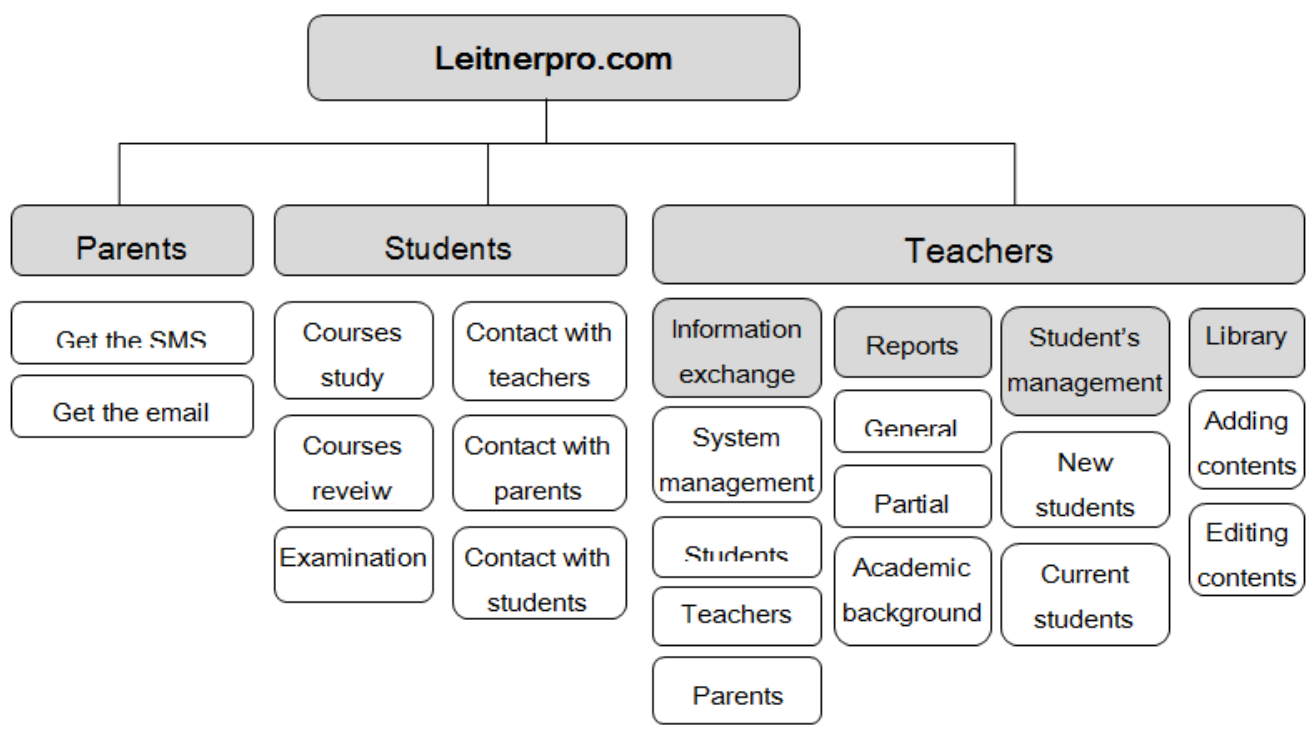

Figure 1. The conceptual model of e-learning features 
The most important abilities of Leitnerpro.com are:

a) Study method; Planning study for each lesson in Leitner ${ }^{1}$ method was automatically step by step questions processing system. In next step, system was asking those questions from students and was processing the next questions with regard to student's ability. Then system had test exam for students every two weeks to enhance the students' abilities for final exams.

b) Supportive strategies; as the system is web based, teachers and also parents can get report automatically over internet. Also the server can send SMS in period of time to parents. Teachers and students can chat with each other's. Therefore, the relationship between Teacher and students were closer by these facilities.

c) System abilities; Teachers can write hyperlinks in cards, so the students will guide to scientific sites to further study.

d) Evaluation; the system was able to do registration records for teachers as well as following up each student progress. Another facility was comparing the student's activities with each other in one class, other classes or schools. There was the possibility of evaluation of booklets materials that were hard to remember. So the teachers can find and edit them. Eventually, this site could reduce the students' educational costs and increase the productivity of schools.

\section{Results}

Results of descriptive statistics of participants' test anxiety, achievement motivation and academic achievement scores in pre-test and post-test are shown in Table 1.

Table 1. Results of descriptive statistics in each group

\begin{tabular}{llcccc}
\hline \multirow{2}{*}{ Index } & \multicolumn{2}{c}{ Mean } & \multicolumn{2}{c}{ Standard Deviation } \\
\cline { 3 - 6 } & & Pre-test & Post- & Pre- & Post-Test \\
\hline \multirow{2}{*}{ Exp. } & Test Anxiety & 12.80 & 11.20 & 0.68 & 0.66 \\
Group & Achievement Motivation & 78.75 & 85.00 & 2.50 & 2.00 \\
& Academic Achievement & 16.00 & 18.66 & 0.23 & 0.12 \\
\hline \multirow{2}{*}{ Cont. } & Test Anxiety & 12.65 & 13.15 & 0.64 & 0.66 \\
Group & Achievement Motivation & 78.33 & 79.00 & 2.47 & 2.52 \\
& Academic Achievement. & 15.45 & 15.75 & 0.20 & 0.24 \\
\hline
\end{tabular}

$$
\mathrm{N}=200
$$

For investigating the effect of e-learning in post-test on participants' test anxiety, achievement motivation and academic achievement with regard to the research conditions,

\footnotetext{
${ }^{1}$ Educational planning method that was introduces by Sebastian Leitner (Jones, 2010). In this method questions were planned in 5 boxes and student has to study the questions and move them from first box in to other four boxes in terms of right or wrong answers.
} 
Covariance test was used. Calculated ANCOVA are presented in Table 2 for test anxiety, achievement motivation and academic achievement at 0.01 significant levels.

Table 2. Tests of Between-Subjects Effects

\begin{tabular}{|c|c|c|c|c|c|c|}
\hline Source & & Sum of Squares & df & Mean & $\mathbf{F}$ & Sig. \\
\hline \multirow{7}{*}{$\begin{array}{l}\text { Dependent } \\
\text { Variable: } \\
\text { anxiety } \\
\text { post-test }\end{array}$} & Corrected Model & 8400.53 & 2 & 4200.27 & 1766.80 & .000 \\
\hline & Intercept & 1.70 & 1 & 1.70 & 0.70 & .401 \\
\hline & Pretest & 8210.41 & 1 & 8210.417 & 3453.60 & .000 \\
\hline & Group & 190.12 & 1 & 190.127 & 80.00 & .000 \\
\hline & Error & 468.34 & 197 & 2.40 & & \\
\hline & Total & 38515.004 & 200 & & & \\
\hline & Corrected Total & 8868.90 & 199 & & & \\
\hline \multirow{7}{*}{$\begin{array}{l}\text { Dependent } \\
\text { Variable: } \\
\text { Achievement } \\
\text { motivation } \\
\text { post-test }\end{array}$} & Corrected Model & 98052.70 & 2 & 49026.34 & 1322.17 & .000 \\
\hline & Intercept & 2751.15 & 1 & 2751.15 & 74.20 & .000 \\
\hline & Pretest & 96288.51 & 1 & 96288.51 & 2596.80 & .000 \\
\hline & Group & 1764.18 & 1 & 1764.18 & 47.60 & .000 \\
\hline & Error & 7304.80 & 197 & 37.08 & & \\
\hline & Total & 1448518.00 & 200 & & & \\
\hline & Corrected Total & 105357.50 & 199 & & & \\
\hline \multirow{7}{*}{$\begin{array}{l}\text { Dependent } \\
\text { Variable: } \\
\text { Academic } \\
\text { Achievement } \\
\text { post-test }\end{array}$} & Corrected Model & 1037.74 & 2 & 518.90 & 748.51 & .000 \\
\hline & Intercept & 105.82 & 1 & 105.82 & 152.66 & .000 \\
\hline & Pretest & 613.61 & 1 & 613.61 & 885.18 & .000 \\
\hline & Group & 424.13 & 1 & 424.13 & 611.84 & .000 \\
\hline & Error & 136.56 & 197 & 0.70 & & \\
\hline & Total & 60385.31 & 200 & & & \\
\hline & Corrected Total & 1174.30 & 199 & & & \\
\hline
\end{tabular}

Results of Scheffe post hoc test represented that differences between means in post-tests were significant for all of the research variables at 0.01 significant levels.

\section{Discussion}

Results of this research represented that e-learning in Leitnerpro.com site with teachers Tele working and parent's virtual presence has a positive effect in high school students' test anxiety, achievement motivation and academic achievement. These results were in line with previous findings (Paechter and colleges, 2010; Intel, 2009; Richard, 2004). Results from Table 1 showed that the test anxiety in the experimental group scored less than control group. Also, achievement motivation and academic achievement in the experimental group scored higher than the control group. Results showed that the test anxiety score in the control group became higher in post-test. This problem may be due to lack of the facilities which was not available to the control group and that participants in the experimental group had all of them; support of parents, daily educational planning in site, daily exams in site and full virtual 
control of teachers. Researchers found that parents-students and teachers- students interaction and potentiality to access to courses materials can give a great visibility to parents and teachers about students' schoolwork and homework (Gate \& Gate, 2004). Studies have shown that teachers' and parents' control and support is effective in students' achievement (Radescu \& Davidescu, 2010). Oraifige and collages (2006) showed that e-learning in web is useful as a learning tool for students. According to their results, e-learning makes learners to have access on learning processes. The developed system (Leitnerpro.com) makes teachers and parents to have access to students learning process too. This technology was effective for test anxiety, achievement motivation and academic achievement among high school students.

According to Analyses of Covariance represented in Table 2, the calculated F was significant for all of the variables. Also results of Scheffe post hoc showed there were significantly differences between high school students' test anxiety, achievement motivation and academic achievements' means scores in pre-test and post-test. Therefore, our all research hypotheses were confirmed in this research.

\section{Conclusions}

The results of research represented that e-learning in site with the teachers Tele working and parent's virtual presence were more effective in experimental group. It could reduce the test anxiety and increase the Achievement motivation and academic achievement in high school students. So, expanded of e-learning sites with high abilities for high schools is suggested. This technology can improve students' academic achievement as well as having reached to a certain standard level of education with no access to schools, then by this technology the deprived students can achieve to educational provisions.

\section{References}

[1] G. Andrewartha and S. Wilmot, "Can multimedia meet tertiary educational needs better than the conventional lecture? A Case Study”, Educational Technology, vol. 17, no. 1, (2001), pp. 1-20.

[2] M. Paechter, B. Maier and Macher, "Students' Expectations of and Experiences in E-learning: Their Relation to Learning Achievements and Course Satisfaction”, Computers \& Education, vol. 54, (2010), pp. 222-229.

[3] B. Gate and M. Gate, "One-to-One Laptops in High School Environment: Piscataquis Community High School Study", Mittchel Institute, Final Report, (2004).

[4] H. J. Hermans, "A Questionnaire Measure of Achievement Motivation”, Applied Psychology, vol. 54, (1970), pp. 353-373.

[5] W. A. P. Intel, "Positive Impact of E-Learning", (2009), Http://www.intel.com.

[6] R. G. Jones, "Emerging Technologies: From Memory Places to Spacing Algorithms: Approaches to SecondLanguage Vocabulary Learning", Language Learning \& Technology, vol. 14, no. 2, (2010), pp. 4-11.

[7] Y. G. Katz, "Attitudes Affecting Collage Students' Preferences for Distance Learning”, Computer Assisted Learning, vol. 18, (2002), pp. 2-9.

[8] M. E. Kenny, L. Y. W. Blair, D. L. Blustain, J. Bempachat and J. Seltzer, "Achievement Motivation among Urban Adolescents: Work Hope", Anatomy Support and Achievement-Related Beliefs, Vocational Behaviour, vol. 77, (2010), pp. 205-212.

[9] H. A. Larson and J. R. Rose, "Effects of Deep Breathing and Muscle Relaxation on ACT Scores", Eastern Educational Journal, vol. 40, no. 1, (2011), pp. 11-22.

[10] T. Magnoson, A. Dall and A. T. Chiland, "Compact Set of National and International Documents in the Field of Education", Inclusive Education Coordination Working Group, (2010), http://www.unesco.org/education/pdf/SALAMA_E.pdf. 
[11] A. Oraifige, G. Oakes, A. Falton, D. Heesom and K. Garner, "Conceptual Web-Based Framework in an Interactive Virtual Environment for Distance Learning”, Electronically E-Learning, vol. 4, no. 1, (2006), pp. 61-67.

[12] A. E. Partovi and G. Zandkarimi, Leitnerpro.com site: Asre Sefr O Yek Co. Iran-Tehran, (2010), Http://www.Leitnerpro.com.

[13] R. Radescu and A. Davidescu, "Security and Confidentiality in the Easy Learning On-Line Platform", Applied Electronics and Information Engineering Dept, Romania, (2010), pp. 449-452, http://www.icvl.eu/2010/disc/icvl/documente/pdf/soft/ICVL_SoftwareSolutions_paper15.pdf.

[14] K. L. Richard, "E-learning compared with face to face: Differences in the academic achievement of postgraduate business students", Educational Technology, vol. 20, no. 3, (2004), pp. 316-336.

[15] I. J. Sarason, "Test Anxiety: Theory, Research and Applications", Hillsdale, NJ: Lawrence Erlbaum Associates, (1980).

[16] S. Terrell, "The Effect of Learning Style on Doctoral Course Completion in a Web-Based Learning Environment", Internet and Higher Education, vol. 5, no. 4, (2003), pp. 345-352.

[17] S. M. Yazdi and G. Zandkarimi, "The Importance of Learning Context: A Comparison of Students Academic Achievement among Different Field of Studies Using Virtual Learning”, Planning and Management in Educational System, vol. 5, no. 9, (2012), pp. 44-60. 
International Journal of Education and Learning Vol. 2, No. 2 (2013) 